\title{
Dietary responses of tidal flat macrobenthos to reduction of benthic microalgae: a test for potential use of allochthonous organic matter
}

\author{
Takashi Sakamaki $^{1,2, *}$, John S. Richardson ${ }^{1}$ \\ ${ }^{1}$ Department of Forest Sciences, University of British Columbia, 3041-2424 Main Mall, Vancouver, \\ British Columbia V6T 1Z4, Canada \\ ${ }^{2}$ Present address: Transdisciplinary Research Organization for Subtropics and Island Studies, University of the Ryukyus, \\ 1 Senbaru, Nishihara, Okinawa 903-0213, Japan
}

\begin{abstract}
We experimentally reduced benthic microalgae using opaque rubber canopy covers and observed dietary responses of Corophium spinicorne (amphipod) and Macoma balthica (bivalve) based on $\delta^{13} \mathrm{C}$ and $\delta^{15} \mathrm{~N}$ measurements in 2 estuarine tidal flats. Each of the tidal flats (MA and TE) was predominated by marine- or terrestrial-origin organic matter (OM), respectively. We hypothesised that the reduction of benthic microalgae correspondingly decreases the proportion of macrobenthos diet attributable to benthic microalgae, and enhances their assimilation of allochthonous OM. Our canopy treatment reduced chlorophyll $a$ in the surface sediment by 35 to $40 \%$. While $\delta^{13} \mathrm{C}$ and $\delta^{15} \mathrm{~N}$ of $M$. balthica were not affected by the canopy treatment, the signatures of $C$. spinicorne were significantly altered at both sites. In MA, the canopy treatment reduced the nutritional dependence of $C$. spinicorne on benthic microalgae and maintained their substantial dependence on the marine-origin $\mathrm{OM}$ predominating in the sediment. On the contrary, in TE, the canopy treatment enhanced the nutritional dependence of C. spinicorne on benthic microalgae and lowered their dependence on the terrestrial-origin OM predominating in the sediment. The canopy treatment significantly changed the C:N and $\delta^{15} \mathrm{~N}$ of the sediment OM in TE. This suggests that benthic microalgae affected biogeochemical processes and the chemical properties of OM in the sediment subsurface. Benthic microalgae may have indirectly controlled nutritional utilisation of terrestrial-origin OM in the sediment by macrobenthos. Overall, the dietary compositions of macrobenthos did not always vary in proportion to the relative abundance of OM sources; the chemical properties of allochthonous $\mathrm{OM}$, its biogeochemical alterations and species-specific food selectivity are also important factors.
\end{abstract}

KEY WORDS: Stable isotopes · Benthic microalgae - Canopy experiment - Corophium spinicorne (amphipod) · Macoma balthica (bivalve) · Trophic shift · Estuary · Forested and agricultural watersheds

Resale or republication not permitted without written consent of the publisher

\section{INTRODUCTION}

Estuarine tidal flats receive allochthonous organic matter (OM) from both marine and river systems and are depositional, long-term repositories for these mixtures (Thornton \& McManus 1994, Sakamaki \& Richardson 2008a,b). Tidal flats are also known to have high productivity of benthic microalgae due to advantageous conditions for their production (e.g. light and nutrients). Thus, primary consumer macrobenthos of tidal flats potentially have various food sources of both allochthonous and autochthonous OM available. However, allochthonous OM, which is provided to or pooled in tidal flats, has not been evaluated from the perspective of its relative assimilability for primary consumer macrobenthos or its potential to be an alternative food source and stabilise food webs.

In many tidal flats, previous studies demonstrated that benthic microalgae were the most important food source for macrobenthos, compared with other OM 
sources (Lee 2000, Kang et al. 2003, Yokoyama \& Ishihi 2003). In such cases, macrobenthos were expected to selectively feed on benthic microalgae, since, in general, the contribution of benthic microalgae to the OM pool of tidal flat sediment is small (Cook et al. 2004, Sakamaki \& Nishimura 2006). However, the contribution of benthic microalgae to macrobenthos diets is likely site- and species-dependent (Doi et al. 2005, Sakamaki et al. unpubl. data); other studies have reported that macrobenthos nutritionally depended upon marine phytoplankton (Yokoyama et al. 2005) or riverorigin OM (Kasai \& Nakata 2005). To date, it is unclear which factors control the relative importance of autochthonous and allochthonous OM in estuarine tidal flat food webs.

The types of allochthonous OM transported into estuaries have various biogeochemical properties owing to their origins. Whereas marine-origin OM is usually dominated by phytoplankton, OM transported through rivers can contain various components, e.g. algae, terrestrial plants and wastes of human activities, and its chemical properties are greatly dependent on watershed conditions (Hopkinson et al. 1998, Sakamaki \& Richardson 2008b). In general, there are distinct differences in chemical properties between terrestrial plants and algae. OM from terrestrial plants has relatively higher contents of cellulose and lignin and a lower content of protein. Algal-origin OM is nitrogen-rich, degradable and also nutritious for organisms (e.g. Enríquez et al. 1993). It has been reported that chemical properties of sediment $\mathrm{OM}$ in some estuarine tidal flats are dependent on the quantity and quality of OM transported from rivers (Sakamaki \& Richardson 2008b, Sakamaki et al. unpubl. data). Furthermore, such chemical properties of allochthonous OM can greatly affect its dynamics and nutritional contribution to estuarine tidal flat macrobenthos (Sakamaki \& Richardson 2008b).

Our primary question was whether allochthonous $\mathrm{OM}$ is a readily consumed food source for primary consumer macrobenthos in tidal flats that can potentially stabilise tidal flat food webs as a substitutable food source. To examine this question, we experimentally reduced benthic microalgal productivity using canopy covers in the field and compared the macrobenthos diets between canopy and control (uncovered) plots based on stable isotope analysis. Specifically, we tested the hypothesis that reduced benthic microalgae promote the consumption of an allochthonous OM source by macrobenthos invertebrates, such as OM transported from marine and river systems, and lower their dietary dependence on benthic microalgae. In addition, we examined how chemical properties of OM predominant in the sediment influence the nutritional shifts of macrobenthos.

\section{MATERIALS AND METHODS}

Study sites. Our field experiment was conducted in 2 estuarine tidal flats (TE and MA) near Vancouver, British Columbia, Canada $\left(49^{\circ} 03^{\prime}\right.$ to $17^{\prime} \mathrm{N}, 122^{\circ} 50^{\prime}$ to $\left.55^{\prime} \mathrm{W}\right)$. The TE (terrestrial) estuary receives inputs from small streams connected to watersheds with forested, mountainous areas in their upper to middle reaches as well as urbanized areas in their lower reaches. The MA (marine) estuary has a river input from a watershed dominated by agricultural land-use areas. Our previous research has shown that the sediment in TE is abundant in terrestrial-origin $\mathrm{OM}$, with a high $\mathrm{C}: \mathrm{N}$ ratio, whereas the sediment in MA is predominated by marine-origin $\mathrm{OM}$, without measurable evidence of terrestrial-origin or riverine-origin OM (Sites FR and AG1 in Sakamaki \& Richardson 2008b). The previous study also showed that 2 species of macrobenthos were common to both tidal flats, i.e. Corophium spinicorne (amphipod) and Macoma balthica (bivalve).

Canopy experiment. We set up experimental canopies to reduce irradiance to the sediment surface and suppress primary productivity of benthic microalgae in the tidal flats. In each tidal flat, 3 canopies of $100 \times$ $100 \mathrm{~cm}$ opaque, rubber sheets (1 $\mathrm{mm}$ thickness) were suspended with a wooden frame on stakes $25 \mathrm{~cm}$ above the sediment and paired with 3 control plots of similar area marked with wooden stakes in undisturbed sediment. The plots were set up about $3 \mathrm{~m}$ apart from each other. The percentage reduction of the 400 to $700 \mathrm{~nm}$ wavelength photon flux by the canopies was about $98 \%$ (light meter: Apogee, BQM). The experiment plots were set in the intertidal zones, and the canopy covers were submerged at high tides. The maximum water depth at the canopies was approximately $2 \mathrm{~m}$ during the experiment period. The canopy experiment was started on August 1, 2005, in both tidal flats and lasted $1 \mathrm{mo}$. During the experiment, there was no significant growth of biofilms on the canopy surfaces or captures of drift by the experiment structures.

At the end of the experiment, surface sediment and macrobenthos samples were collected from the canopy and control plots. The sediment samples were collected from 2 points in each plot using a core sampler with $4 \mathrm{~cm}$ diameter. For the macrobenthos sampling, the sediment in each plot was collected from 2 areas of $225 \mathrm{~cm}^{2}$ in each plot, and then sifted on a $1 \mathrm{~mm}$ sieve. In the laboratory, all individuals of Macoma balthica with $<1 \mathrm{~cm}$ shell length and Corophium spinicorne were picked up by tweezers from the $1 \mathrm{~mm}$ sieve and counted.

To test whether the canopies affected depositional flux of particulate materials from the water columns, a supplemental experiment was also conducted. For each of the canopy and control treatments in TE, a total of 8 tube-shaped sediment traps $(3 \mathrm{~cm}$ in diameter 
and $12 \mathrm{~cm}$ in height) were inserted into sediments, and their upper rim was adjusted to $2 \mathrm{~cm}$ above the sediment surface. Three days later, 15 traps were collected in total (one control sample was disturbed and not counted). The total dry mass of trapped material was measured in the laboratory.

Sample analyses. One subsample of the surface sediment layer of $13 \mathrm{~mm}$ diameter and $10 \mathrm{~mm}$ depth was obtained from each sediment core sample and soaked in $\sim 20 \mathrm{ml}$ of $90 \%$ acetone to extract chlorophyll a (chl a) and phaeophytin a (phaeo a). Chl $a$ and phaeo a were determined using a spectrophotometer (Spectronic 20, Bausch \& Lomb) following Lorenzen's (1967) method. A sediment subsample for stable isotope analysis was also obtained from each sediment core sample. Two subsamples of a few to several individuals of each macrobenthos species were made from each plot for stable isotopic measurement. For Macoma balthica, only their foot part was processed for stable isotope analysis. Twenty-four subsamples ( 2 tidal flats $\times 2$ types of treatments $\times 3$ plots $\times 2$ replicates) were made for each measurement in most cases. However, only 1 subsample of $M$. balthica was obtained at 3 plots in MA, due to the low density, so 21 subsamples were made for M. balthica in total.

The sediment and macrobenthos subsamples for stable isotope analysis were acidified in $10 \% \mathrm{HCl}$, washed with distilled water and dried in an oven $\left(60^{\circ} \mathrm{C}\right)$. The carbon and nitrogen stable isotopic compositions of the sediment and macrobenthos samples were determined by a continuous flow, isotope ratio, mass spectrometer system (Hydra 20/20, Europa) at the Stable Isotope Facility of the University of California at Davis. Isotopic compositions were reported as parts per thousand deviations (\%) from Pee Dee Belemnite for carbon $\left(\delta^{13} \mathrm{C}\right)$ and from air for nitrogen $\left(\delta^{15} \mathrm{~N}\right)$. For sediment samples, their carbon and nitrogen contents were also obtained as a percentage of dry mass.

Statistical analyses. Analyses of variance (ANOVAs) were applied to test for effects of estuaries, experimental treatment and their interaction on the chemical properties of the sediment and on the density and stable isotopic signatures of the macrobenthos. We used PROC MIXED of SAS Version 9.1 (SAS, Inc.) for these analyses. In addition, to contrast canopy plots with control plots, least-squares means were compared. The significant difference was judged by the criteria of $p<0.05$.

Interpretation of stable isotope results. We compared the $\delta^{13} \mathrm{C}$ and $\delta^{15} \mathrm{~N}$ data obtained from the present study with the $\delta^{13} \mathrm{C}$ and $\delta^{15} \mathrm{~N}$ data of potential OM sources that were determined at the experiment sites in our previous study (Sakamaki \& Richardson 2008b). In that study, fine particulate OM $(<1 \mathrm{~mm}$, FPOM) of river water was sampled monthly from the rivers flowing into the estuaries of the present study from July
2004 to September 2005 (12 to 14 times). FPOM of offshore surface $(<50 \mathrm{~cm}$ depth) seawater was collected in areas off the studied estuaries in August 2004, February 2005 and October 2005. Benthic microalgae were collected, using a procedure that was slightly modified from a method established by Riera \& Richard (1996), at both the studied tidal flats in August 2004, May 2005 and October 2005. The averages of stable isotopic values from multiple sampling occasions were used as representative values for the OM sources in the present study. The degree of seasonal variation of the stable isotopic signatures of potential sources was evidently smaller than the differences between the sources, at least for $\delta^{13} \mathrm{C} . \delta^{13} \mathrm{C}$ of different sources did not overlap, fell into each of the general ranges, and showed the order commonly found, i.e. riverine particulate organic matter $(\mathrm{POM})<$ marine POM < benthic microalgae. Thus, dietary shifts of macrobenthos were assessed based on the visual observation of the $\delta^{13} \mathrm{C}$ to $\delta^{15} \mathrm{~N}$ biplots. Mixing models were not used in the present study, as the stable isotopic signatures of some benthic macrobenthos were out of the ranges of the signatures for potential OM sources. In particular, the relatively high average values of benthic microalgal $\delta^{15} \mathrm{~N}$ were due to their high $\delta^{15} \mathrm{~N}$ in summer, possibly caused by isotopic fractionation associated with active denitrification under high summer temperatures. The trophic fractionation was considered 1 and $3 \%$ for $\delta^{13} \mathrm{C}$ and $\delta^{15} \mathrm{~N}$, respectively, in this assessment of stable isotope results for macrobenthos (DeNiro \& Epstein 1978, Minagawa \& Wada 1984).

\section{RESULTS}

The supplemental experiment showed that the canopy closure did not cause a significant difference in the depositional flux of particulate material onto the sediment between control and canopy plots ( $t$-test, $\mathrm{df}=$ $13, \mathrm{p}>0.78$ ). Thus, the $25 \mathrm{~cm}$ clearance above the sediment was sufficient to maintain lateral transport of particulate material and its natural deposition.

All the sediment property variables, chl $a$, phaeo $a$, $\mathrm{C}: \mathrm{N}, \delta^{13} \mathrm{C}$ and $\delta^{15} \mathrm{~N}$ differed significantly between the 2 tidal flats: chl $a$, phaeo $a$ and $C: N$ were higher and $\delta^{13} \mathrm{C}$ and $\delta^{15} \mathrm{~N}$ were lower in TE (Table 1, Fig. 1). The sediment chl $a$ in both TE and MA was significantly lower in the canopy plots than in the control plots after the 1 mo experiment duration. Compared with the control plots, the sediment chl a amount in the canopy plot was reduced by 35 and $40 \%$, on average, in TE and MA, respectively. The sediment phaeo $a$ and $\delta^{13} \mathrm{C}$ did not differ significantly between the canopy and control plots in TE or MA. Both sediment $\delta^{15} \mathrm{~N}$ and $\mathrm{C}: \mathrm{N}$ differed significantly between the control and canopy plots in TE, 
Table 1. F-statistics from mixed-model ANOVAs testing for effects of tidal flats, experimental canopy treatment and their interaction on chemical properties of the sediment, and on density and stable isotopic signatures of macrobenthos. Asterisks indicate significant effects: ${ }^{*} p<0.05,{ }^{* *} p<0.01$, ${ }^{* * *} p<0.001$. Degrees of freedom are shown in parentheses

\begin{tabular}{|lccc|}
\hline \multirow{2}{*}{$\begin{array}{l}\text { Dependent } \\
\left(\mathrm{df}_{\text {denominator }}\right)\end{array}$} & $\begin{array}{c}\text { Tidal flats } \\
(1)\end{array}$ & $\begin{array}{c}\text { Treatment } \\
(1)\end{array}$ & $\begin{array}{c}\text { Tidal flats } \times \\
\text { Treatment }(1)\end{array}$ \\
\cline { 2 - 4 } & & & \\
Sediment & & $30.5^{* * *}$ & 0.90 \\
Chlorophyll a (20) & $41.3^{* * *}$ & 1.62 & 0.04 \\
Phaeophytin a (20) & $8.21^{* *}$ & $5.60^{*}$ & 4.22 \\
$\mathrm{C}: \mathrm{N}(20)$ & $464^{* * *}$ & 1.52 & 0.29 \\
$\delta^{13} \mathrm{C}(20)$ & $1103^{* * *}$ & $8.82^{* *}$ & $4.93^{*}$ \\
$\delta^{15} \mathrm{~N}(20)$ & $50.0^{* * *}$ & & \\
Corophium spinicorne & $24.9^{* *}$ & 1.53 & 1.90 \\
Density (8) & $20.0^{* * *}$ & 0.40 & $31.1^{* * *}$ \\
$\delta^{13} \mathrm{C}(20)$ & 0.02 & 0.06 & $9.38^{* *}$ \\
$\delta^{15} \mathrm{~N}(20)$ & & & \\
Macoma balthica & & 0.38 & 0.06 \\
Density (8) & $38.6^{* * *}$ & 0.38 & 0.79 \\
$\delta^{13} \mathrm{C}(17)$ & $105^{* * *}$ & 0.84 & 0.32 \\
$\delta^{15} \mathrm{~N}(17)$ & $64.4^{* * *}$ & 0.18 & \\
\hline
\end{tabular}

whereas neither sediment $\delta^{15} \mathrm{~N}$ nor $\mathrm{C}: \mathrm{N}$ differed significantly in MA. The tidal flats $x$ treatment interaction was significant for $\delta^{15} \mathrm{~N}$. For C:N, that interaction was not significant, but marginal ( $\mathrm{p}=0.053)$.

For both Corophium spinicorne and Macoma balthica, the density was significantly higher in TE than in MA (Table 1). The density of $C$. spinicorne per $450 \mathrm{~cm}^{2}$ was $247 \pm 104$ (mean \pm $\mathrm{SD})$ and $43.5 \pm 21.6$ in TE and MA, respectively. The density of $M$. balthica per $450 \mathrm{~cm}^{2}$ was $26.8 \pm 7.5$ and $5.0 \pm 2.5$ in TE and MA, respectively. Neither the density of C. spinicorne nor that of $M$. balthica differed significantly between the control and canopy plots after the 1 mo canopy experiment in either tidal flat.

For Corophium spinicorne, $\delta^{13} \mathrm{C}$ was significantly lower in TE than in MA, whereas $\delta^{15} \mathrm{~N}$ did not differ significantly (Table 1, Fig. 2). For Macoma balthica, both $\delta^{13} \mathrm{C}$ and $\delta^{15} \mathrm{~N}$ had significantly lower values in TE compared with in MA. C. spinicorne in TE showed significantly higher $\delta^{13} \mathrm{C}$ in the canopy plots than in the control plots after the 1 mo canopy experiment. The mean of $\delta^{15} \mathrm{~N}$ of C. spinicorne in TE was higher in the canopy plots than in the control plots, but the difference was not significant. By contrast, in MA, C. spinicorne was significantly lower in both $\delta^{13} \mathrm{C}$ and $\delta^{15} \mathrm{~N}$ in the canopy plots. For both $\delta^{13} \mathrm{C}$ and $\delta^{15} \mathrm{~N}$ of $C$. spinicorne, the tidal flats $\times$ treatment inter- action was significant. $\delta^{13} \mathrm{C}$ and $\delta^{15} \mathrm{~N}$ of $M$. balthica did not differ significantly between the control and canopy plots in either TE or MA.

The stable isotopic signatures of Corophium spinicorne in the control plots were close to those of sediment OM in both tidal flats (Fig. 3). Meanwhile, the stable isotopic signatures of $C$. spinicorne in the canopy plots tended to deviate from the signatures of sediment $\mathrm{OM}$ in both estuaries. Both $\delta^{13} \mathrm{C}$ and $\delta^{15} \mathrm{~N}$ of C. spinicorne in TE were about $2 \%$ closer to those of benthic microalgae at the canopy plots than at the control plots. On the other hand, both $\delta^{13} \mathrm{C}$ and $\delta^{15} \mathrm{~N}$ of $C$. spinicorne in MA deviated about $2 \%$ more from those of benthic microalgae at the canopy plots than at the control plots. $\delta^{15} \mathrm{~N}$ of $C$. spinicorne in the canopy plots of MA was lower than that of marine-origin OM and sediment OM, but their $\delta^{13} \mathrm{C}$ remained close to marine-origin OM. The stable isotopic signatures of $M$. balthica of both TE and MA were relatively close to those of benthic microalgae, compared with the other potential OM sources.
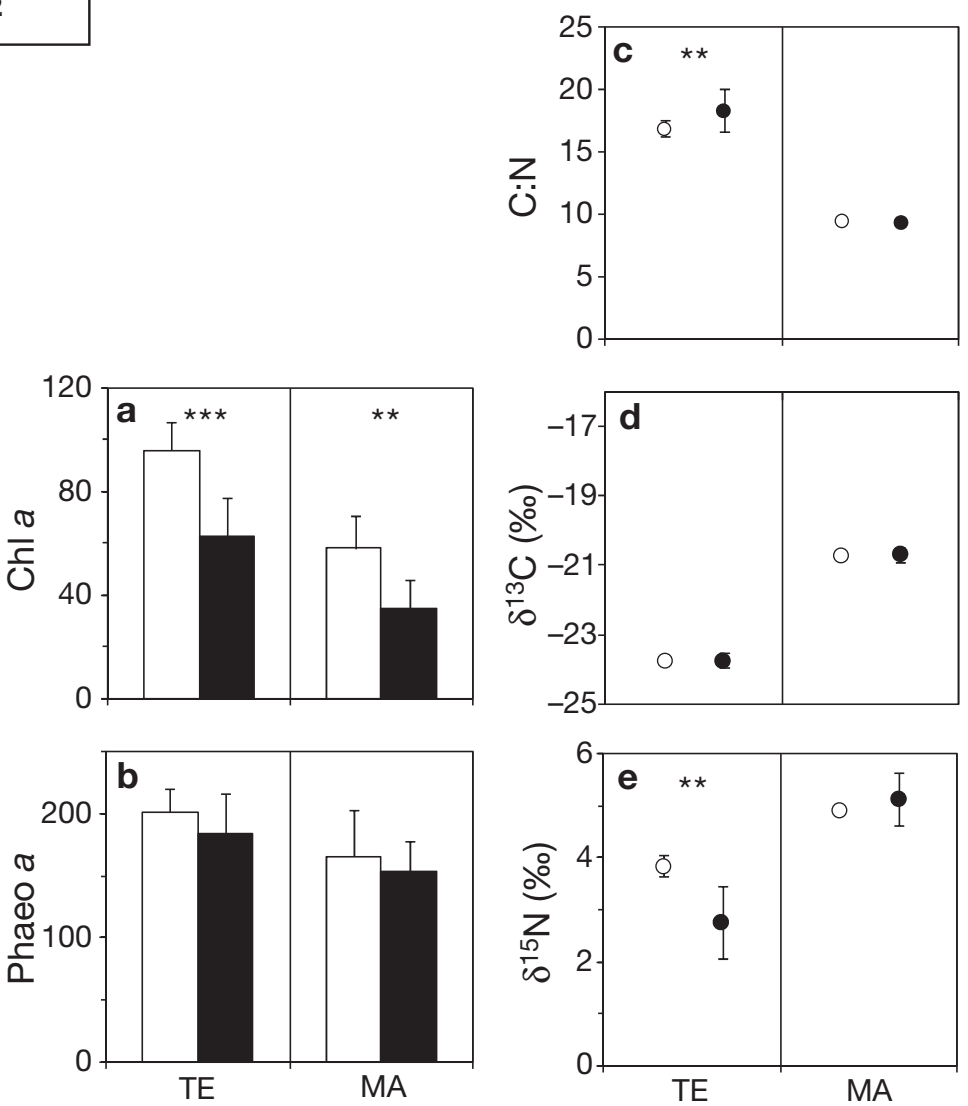

Fig. 1. (a) Chlorophyll $a_{1}$ (b) phaeophytin $a_{1}$ (c) C:N, (d) $\delta^{13} \mathrm{C}$ and (e) $\delta^{15} \mathrm{~N}$ of tidal flat surface sediments after 1 mo canopy treatment in 2 study estuaries, TE and MA. Open and solid bars/circles represent control and canopy plots, respectively. Error bars $=1$ standard deviation. Asterisks indicate a significant difference between control and canopy plots within each estuary (pairwise comparisons of least-squares means: ${ }^{*} p<0.05$, $\left.{ }^{* *} \mathrm{p}<0.01,{ }^{* * *} \mathrm{p}<0.001\right)$ 

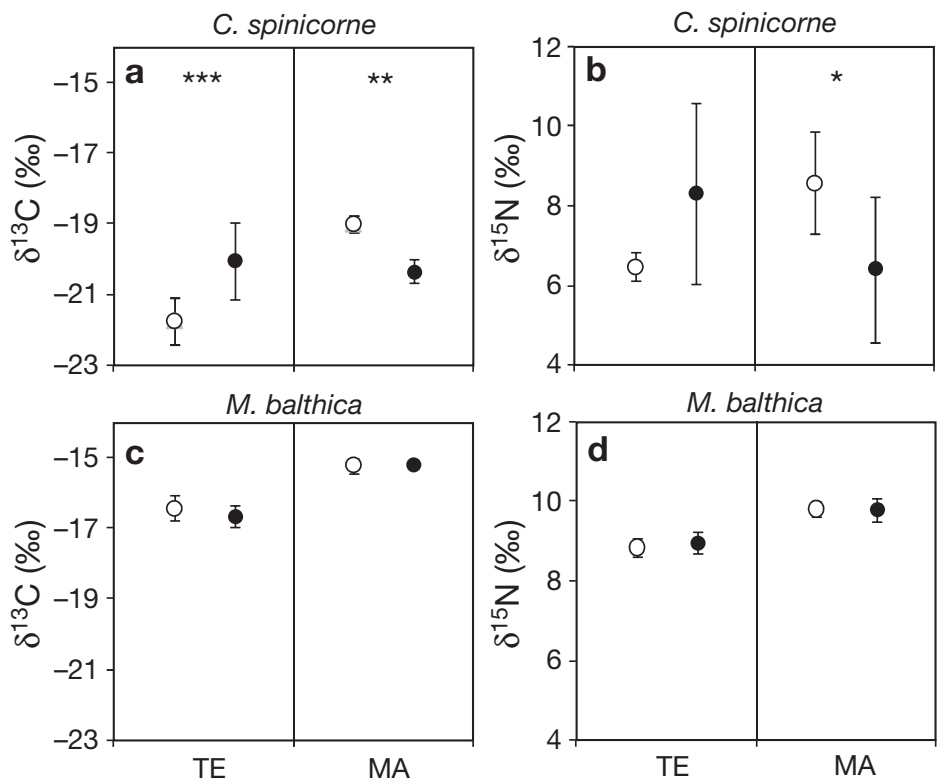

Fig. 2. (a,c) $\delta^{13} \mathrm{C}$ and $(\mathrm{b}, \mathrm{d}) \delta^{15} \mathrm{~N}$ of studied tidal flat macrobenthos $(\mathrm{a}, \mathrm{b})$ Corophium spinicorne or (c,d) Macoma balthica after 1 mo canopy treatment in the 2 study estuaries, TE and MA. Open and solid circles represent control and canopy plots, respectively. Error bars = 1 standard deviation. Asterisks indicate significant difference between control and canopy plots within each estuary (pairwise comparisons of least-squares means: $\left.{ }^{*} \mathrm{p}<0.05,{ }^{* *} \mathrm{p}<0.01,{ }^{* * *} \mathrm{p}<0.001\right)$

\section{DISCUSSION}

The significant differences in $\delta^{13} \mathrm{C}$ and $\delta^{15} \mathrm{~N}$ of Corophium spinicorne between control and canopy plots, which were found in TE and MA, suggest their shift of food resources due to the canopy treatment. The result for C. spinicorne in MA was supportive of our hypothesis; the nutritional dependence of C. spinicorne on benthic microalgae was lowered under the reduction of benthic microalgae. $\delta^{13} \mathrm{C}$ values of C. spinicorne in the canopy plots suggest slightly increased dependence on the abundant allochthonous OM, i.e. of marine origin. The result in MA is also consistent with some previous studies that compared shaded and unshaded plots in other types of habitats (e.g. salt marshes and streams); they showed higher dependence of primary consumers' diets on autochthonously produced algae in the unshaded plots (e.g. Doi et al. 2007, Whitcraft \& Levin 2007). However, the result from TE did not support our hypothesis. Contrary to our expectation, the stable isotope results suggest that C. spinicorne in the shaded plots increased their assimilation of benthic microalgae despite the reduced benthic microalgal abundance and decreased their assimilation of the abundant allochthonous OM, i.e. of terrestrial origin.

The different responses of Corophium spinicorne to the canopy treatment between the 2 estuaries may be
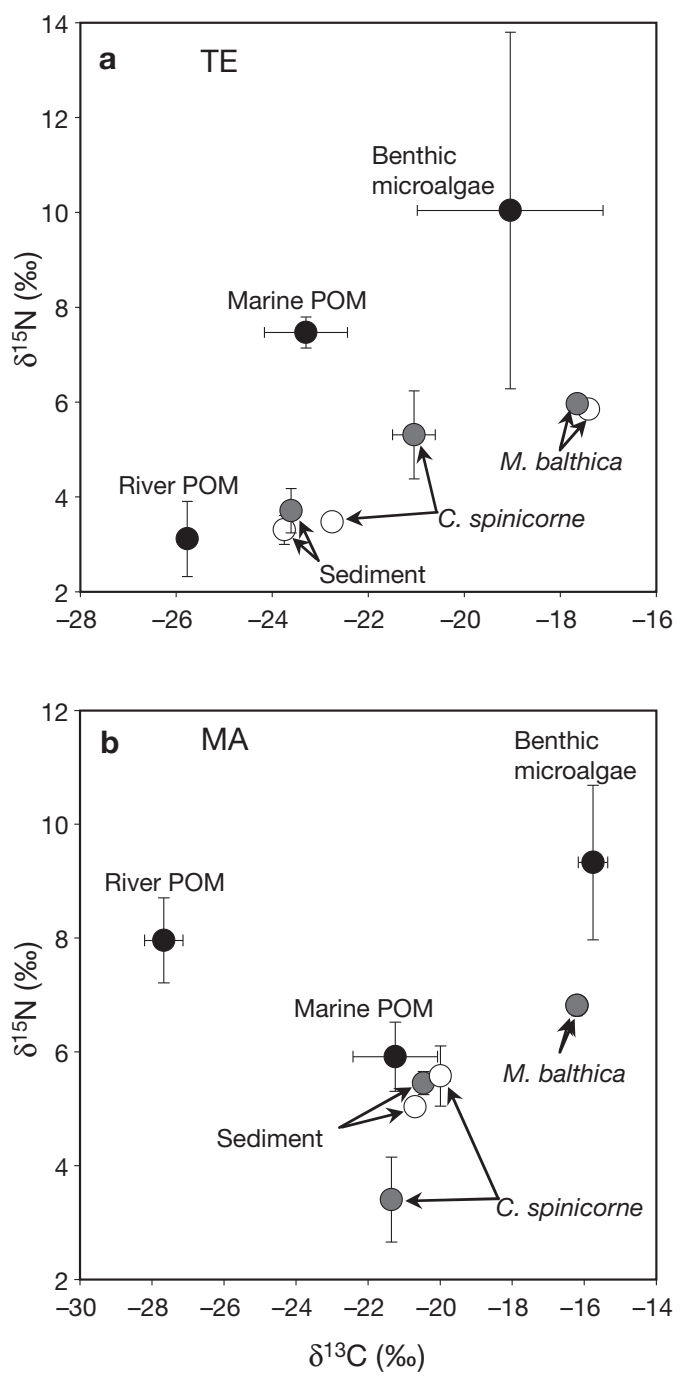

Fig. 3. Comparisons of $\delta^{13} \mathrm{C}$ and $\delta^{15} \mathrm{~N}$ results for both tidal flats $(\mathrm{a}, \mathrm{b})$ from the present study with $\delta^{13} \mathrm{C}$ and $\delta^{15} \mathrm{~N}$ for organic matter sources potentially contributing to tidal flat organic matter pools. $\delta^{13} \mathrm{C}$ and $\delta^{15} \mathrm{~N}$ for organic matter sources are averages from multiple sampling occasions across different seasons, which are interpolated from our previous study (Sakamaki \& Richardson 2008b). For sediment and macrobenthos results, which were obtained in the present study, open and gray circles represent control and canopy plots, respectively. For macrobenthos results, 1 and $3 \%$ were subtracted from raw data of $\delta^{13} \mathrm{C}$ and $\delta^{15} \mathrm{~N}$, respectively, to account for trophic fractionation. Solid circles represent potential organic matter sources. Error bars $=1$ standard error (river POM: $\mathrm{n}=12$ to 14 ; marine POM: $\mathrm{n}=3$; benthic microalgae: $\mathrm{n}=3$; Corophium spinicorne and sediment: $\mathrm{n}=6$; Macoma balthica: $\mathrm{n}=3$ to 6 )

attributable to the different nutritional availability of allochthonous OM predominating in the sediments. In general, terrestrial-origin $\mathrm{OM}$ with high $\mathrm{C}: \mathrm{N}$ is less nutritious, whereas marine-origin OM mainly consists of phytoplankton and can be more readily assimilated by macrobenthos. In $\mathrm{TE}$, the relatively lower nutritional value of terrestrial-origin OM may have pre- 
vented its contribution as a substitutable food source. On the contrary, in MA, the relatively nutritious marine-origin OM predominating in the sediment may have turned into a substitutable food resource for C. spinicorne when benthic microalgae were reduced. However, the above explanation could be confounded by the fact that benthic microalgae were more abundant in TE than in MA. The canopy treatment in MA may have caused more severe shortage of benthic microalgae for $C$. spinicorne and thus facilitated the trophic shift to the abundant allochthonous OM, i.e. of marine origin. On the other hand, in TE, benthic microalgae may have remained sufficiently abundant for C. spinicorne even in the canopy plots, enabling C. spinicorne to continue utilising benthic microalgae.

The oxygen provision and nutrient uptake by benthic microalgae are tightly linked with various microbial metabolisms and nitrogen dynamics at watersediment interfaces (e.g. Rysgaard et al. 1995, Sundbäck et al. 2000, Sakamaki et al. 2006). In particular, denitrification and nitrification fractionate stable isotopes of ambient inorganic N (Minagawa \& Wada 1984, Wada \& Hattori 1991) and potentially affect the $\delta^{15} \mathrm{~N}$ of sediment OM through uptake of inorganic $\mathrm{N}$ by bacteria growing on sediment OM. The different $\delta^{15} \mathrm{~N}$ and $\mathrm{C}: \mathrm{N}$ values of sediment OM between the canopy and control plots in TE suggest that the nitrogen dynamics were changed by the reduced productivity of benthic microalgae. Meanwhile, the bacterial production on low-nitrogen-content detritus enhances the nutritional value of the detritus by incorporating nitrogen from ambient water (Tenore 1977, Tenore \& Hanson 1980, Caraco et al. 1998). Such bacterial metabolisms are also activated by benthic microalgal production of oxygen and extracellular metabolites (Epping \& Jørgensen 1996, Middelburg et al. 2000, Cook et al. 2007). Thus, particularly in TE, the reduction of benthic microalgal productivity may have lowered the nutritional availability of terrestrial-origin OM, which is originally relatively less nutritious. This is supported in part by the result from TE that the C:N of sediment OM was higher in the canopy plots than in the control plots. Furthermore, these may explain the lowered dependence of Corophium spinicorne on terrestrial-origin OM.

The significant change of stable isotopic signatures of Corophium spinicorne caused by the canopy treatment indicates the plasticity of their diet composition. The diet of $C$. spinicorne was likely tightly associated with local, deposited food resource compositions, although this species is mobile and likely possible to move into/out of the plots. On the contrary, the diet of Macoma balthica was not significantly altered by the canopy treatment in either of the estuaries, despite their tight nutritional linkage with benthic microalgae.
One possible explanation for this result could be that benthic algae resuspended into the water column may have been transported into the canopy plots (de Jonge \& van Beusekom 1992) and utilised by M. balthica through their suspension feeding. However, both $C$. spinicorne and $M$. balthica can practice both suspension and deposit feeding and can shift their foraging behaviours in response to various environmental factors (e.g. predation risk, water current, food availability) (Peterson \& Skilleter 1994, Riisgård \& Kamermans 2001). Thus, their feeding mode does not simply explain the difference in dietary responses to the canopy treatment between the 2 species. Further examinations are necessary to clarify which mechanisms control the food selection and plasticity of these species.

Some studies have shown that tidal flat macrobenthos change their food source composition, responding to allochthonous OM inputs and autochthonous OM production (e.g. Kang et al. 1999). This implies that dietary compositions of macrobenthos are proportional to the relative abundance of organic matter of different origins. The increased dependence of Corophium spinicorne on marine POM in the canopy plot of MA was supportive of this idea. However, the dietary composition of macrobenthos is not always proportional to the relative abundance of OM sources. Our experimental result for C. spinicorne in the canopy plot of TE suggests that the nutritional availability of allochthonous OM, particularly with originally low nutrition value, depends on biogeochemical processes, i.e. the nutrient dynamics and qualitative alteration of OM linked with benthic microalgal metabolisms. In addition, our results for Macoma balthica suggest that macrobenthos can be highly selective for one particular source regardless of its relative abundance. Overall, our experiment results underline that the nutritional utilisation of allochthonous OM by macrobenthos depends not only on the relative abundance of different OM sources, but also on the chemical properties of allochthonous OM, its modification by biogeochemical processes and the food selectivity by macrobenthos.

Our results also suggest that there are 3 potential responses of macrobenthos diets to the reduction of benthic microalgal production: dietary shift due to the change in the relative abundance of different OM sources, dietary shift due to qualitative alternation of OM in sediment, and no dietary shift due to strong food selectivity for a particular OM source. This implies that benthic microalgae can influence dietary composition of tidal flat macrobenthos in diverse ways. Further studies are necessary in order to untangle the complex linkages between benthic microalgae, allochthonous $\mathrm{OM}$ and macrobenthos, and to enhance the understanding of estuarine tidal flat food webs. 
Acknowledgements. We thank G. Harrison, K. Zeron and J. Shum for assistance with field and laboratory work. The present study was financially supported by the Japan Society for the Promotion of Science and the Natural Sciences and Engineering Research Council of Canada.

\section{LITERATURE CITED}

Caraco NF, Lampman G, Cole JJ, Limburg KE, Pace ML, Fischer D (1998) Microbial assimilation of DIN in a nitrogen rich estuary: implications for food quality and isotope studies. Mar Ecol Prog Ser 167:59-71

Cook PLM, Revill AT, Clementson LA, Volkman JK (2004) Carbon and nitrogen cycling on intertidal mudflats of a temperate Australian estuary. III. Sources of organic matter. Mar Ecol Prog Ser 280:55-72

Cook PLM, Veuger B, Böer S, Middelburg JJ (2007) Effect of nutrient availability on carbon and nitrogen incorporation and flows through benthic algae and bacteria in nearshore sandy sediment. Aquat Microb Ecol 49:165-180

$>$ de Jonge VN, van Beusekom JEE (1992) Contribution of resuspended microphytobenthos to total phytoplankton in the Ems estuary and its possible role for grazers. Neth J Sea Res 30:91-105

> DeNiro MJ, Epstein S (1978) Influence of diet on the distribution of carbon isotopes in animals. Geochim Cosmochim Acta 42:495-506

Doi H, Matsumasa M, Toya T, Satoh N, Mizota C, Maki Y, Kikuchi E (2005) Spatial shifts in food sources for macrozoobenthos in an estuarine ecosystem: carbon and nitrogen stable isotope analyses. Estuar Coast Shelf Sci 64:316-322

> Doi H, Takemon Y, Ohta T, Kikuchi E (2007) Effect of reachscale canopy cover on trophic pathways of caddisfly larvae in a Japanese mountain stream. Mar Freshw Res 58: 811-817

Enríquez S, Duarte CM, Sand-Jensen K (1993) Patterns in decomposition rates among photosynthetic organisms: the importance of detritus C:N:P content. Oecologia 94: 457-471

Epping EHG, Jørgensen BB (1996) Light-enhanced oxygen respiration in benthic phototrophic communities. Mar Ecol Prog Ser 139:193-203

Hopkinson CS, Buffam I, Hobbie J, Vallino J and others (1998) Terrestrial inputs of organic matter to coastal ecosystems: an intercomparison of chemical characteristics and bioavailability. Biogeochemistry 43:211-234

Kang CK, Sauriau PG, Richard P, Blanchard GF (1999) Food sources of the infaunal suspension-feeding bivalve Cerastoderma edule in a muddy sandflat of Marennes-Oléron Bay, as determined by analyses of carbon and nitrogen stable isotopes. Mar Ecol Prog Ser 187:147-158

Kang CK, Kim JB, Lee KS, Kim JB, Lee PY, Hong JS (2003) Trophic importance of benthic microalgae to macrozoobenthos in coastal bay systems in Korea: dual stable C and N isotope analysis. Mar Ecol Prog Ser 259:79-92

Kasai A, Nakata A (2005) Utilization of terrestrial organic matter by the bivalve Corbicula japonica estimated from stable isotope analysis. Fish Sci 71:151-158

Lee SY (2000) Carbon dynamics of Deep Bay, eastern Pearl River estuary, China. II. Trophic relationship based on carbon- and nitrogen-stable isotopes. Mar Ecol Prog Ser 205:1-10

Lorenzen CJ (1967) Determination of chlorophyll and pheopigments: spectrophotometric equations. Limnol Oceanogr $12: 343-346$

Editorial responsibility: Hans Heinrich Janssen, Oldendorf/Luhe, Germany
Middleburg JJ, Barranguet C, Boschker HTS, Herman PMJ, Moens T, Heip CHR (2000) The fate of intertidal microphytobenthos carbon: an in situ ${ }^{13} \mathrm{C}$-labeling study. Limnol Oceanogr 45:1224-1234

> Minagawa M, Wada E (1984) Stepwise enrichment of ${ }^{15} \mathrm{~N}$ along food chains: further evidence and the relation between $\delta^{15} \mathrm{~N}$ and animal age. Geochim Cosmochim Acta 48:1135-1140

- Peterson CH, Skilleter GA (1994) Control of foraging behavior of individuals within an ecosystem context: the clam Macoma balthica, flow environment, and siphon-cropping fishes. Oecologia 100:256-267

> Riera P, Richard P (1996) Isotopic determination of food source of Crassostea gigas along a trophic gradient in the estuarine bay of Marennes-Oleron. Estuar Coast Shelf Sci 42:347-360

Riisgård HU, Kamermans P (2001) Switching between depositand suspension-feeding in coastal zoobenthos. In: Reise $\mathrm{K}$ (ed) Ecological studies, ecological comparisons of sedimentary shores. Springer, Berlin, p 73-101

> Rysgaard S, Christensen PB, Nielsen LP (1995) Seasonal variation in nitrification and denitrification in estuarine sediment colonized by benthic microalgae and bioturbating infauna. Mar Ecol Prog Ser 126:111-121

Sakamaki T, Nishimura O (2006) Dynamic equilibrium of sediment carbon content in an estuarine tidal flat: characterization and mechanism. Mar Ecol Prog Ser 328:29-40

Sakamaki T, Richardson JS (2008a) Retention, breakdown and biological utilisation of deciduous tree leaves in an estuarine tidal flat of southwestern British Columbia, Canada. Can J Fish Aquat Sci 65:38-46

> Sakamaki T, Richardson JS (2008b) Effects of small rivers on chemical properties of sediment and diets for primary consumers in estuarine tidal flats: a comparison between forested and agricultural watersheds. Mar Ecol Prog Ser 360:13-24

> Sakamaki T, Nishimura O, Sudo R (2006) Tidal time scale variation in nutrient flux across the sediment-water interface of an estuarine tidal flat. Estuar Coast Shelf Sci 67: $653-663$

> Sundbäck K, Miles A, Goransson E (2000) Nitrogen fluxes, denitrification and the role of microphytobenthos in microtidal shallow-water sediments: an annual study. Mar Ecol Prog Ser 200:59-76

Tenore KR (1977) Growth of Capitella capitata cultured on various levels of detritus derived from difference sources. Limnol Oceanogr 22:936-941

Tenore KR, Hanson RB (1980) Availability of detritus of different types and ages to a polychaete macroconsumer, Capitella capitata. Limnol Oceanogr 25:553-558

Thornton SF, McManus J (1994) Application of organic carbon and nitrogen stable isotope and $\mathrm{C} / \mathrm{N}$ ratio as source indicator of organic matter provenance in estuarine systems: evidence from the Tay Estuary, Scotland. Estuar Coast Shelf Sci 38:219-233

Wada E, Hattori A (1991) Nitrogen in the sea: forms, abundances, and rate processes. CRC Press, Boca Raton, FL

Whitcraft CR, Levin LA (2007) Regulation of benthic algal and animal communities by salt marsh plants: impact of shading. Ecology 88:904-917

Yokoyama H, Ishihi Y (2003) Feeding of the bivalve Theora lubrica on benthic microalgae: isotopic evidence. Mar Ecol Prog Ser 255:303-309

- Yokoyama H, Tamaki A, Koyama K, Ishihi Y, Shimada K, Harada K (2005) Isotopic evidence for phytoplankton as a major food source for macrobenthos on an intertidal sandflat in Ariake Sound, Japan. Mar Ecol Prog Ser 304:101-116 